\title{
Intrastratal flow in the Cretaceous Gyeokpori Formation (SW South Korea)
}

\author{
Uk Hwan BYUN ${ }^{1}$, A.J. (Tom) VAN LOON², Yi Kyun KWON³ and Kyoungtae KO ${ }^{1, *}$ \\ 1 Korea Institute of Geoscience and Mineral Resources (KIGAM), Geology Division, Daejeon 34132, South Korea \\ 2 Shandong University of Science and Technology, College of Earth Science and Engineering, Qingdao 266590, \\ Shandong, China \\ 3 Kongju National University, Department of Geoenvironmental Sciences, Kongju 314-701, South Korea
}

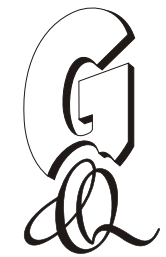

Byun, U.H., Van Loon, A.J. (Tom), Kwon, Y.K., Ko, K., 2020. Intrastratal flow in the Cretaceous Gyeokpori Formation (SW South Korea). Geological Quarterly, 64 (3): 611-625, doi: 10.7306/gq.1548.

\begin{abstract}
Intrastratal flow is a process that is still poorly understood, rarely described and difficult to interpret in ancient rocks. Sediments in the Cretaceous lacustrine Gyeokpori Formation of southwestern South Korea contain some chaotically deformed sandstone layers with deformed mudstone clasts that are ascribed to this process. The interpretation is based on the fact that these layers cannot be explained as a result of subaqueous debris flows or mass transport, whereas the sedimentary context, including the presence of other soft-sediment deformation structures, indicates that intrastratal flow must have been physically possible. The sedimentary setting was a lake in which mainly siliciclastic rocks were deposited, with some interbedded volcaniclastics. The nearby volcanic activity caused seismic shocks that affected the unstable lake margins resulting in the dominance of gravity-flow deposits, but also in a high sedimentation rate that facilitated soft-sediment deformation partly caused by intrastratal flow. This must have happened fairly frequently during a probably limited time-span, as several layers showing traces of intrastratal flow are present within a succession of only $<1 \mathrm{~m}$ thick. The combined data on the geological setting and our findings regarding the origin of the various soft-sediment deformation structures may help to recognize the traces left by intrastratal flow elsewhere in the geological record.
\end{abstract}

Key words: intrastratal flow, Gyeokpori Formation, soft-sediment deformation structures, lacustrine environment, Cretaceous.

\section{INTRODUCTION}

Intrastratal flow in ancient rocks can be interpreted only on the basis of traces left by the process. Such traces consist almost exclusively of soft-sediment deformation structures (SSDS; this acronym is used here for both singular and plural). This poses a problem as SSDS of numerous types are known to have several possible origins. Moreover, even for sediments accumulated in specific sedimentary environments such as the lake deposits under study here, SSDS with largely different origins have been reported frequently in the past few decades (e.g., Sims, 1973, 1975; Hempton and Dewey, 1983; Alfaro et al., 1997; Rodríguez-Pascua et al., 2000; Moretti and Sabato, 2007; Taşgín and Türkmen, 2009; Gibert et al., 2011; Taşgín et al., 2011). All these studies emphasize that the deformational processes cannot always be reconstructed with certainty, because small differences in sediment characteristics or depositional processes can lead to entirely different SSDS. To make interpretations of SSDS even more complex, different causes might lead to the development of very similar SSDS.

\footnotetext{
* Corresponding author, e-mail: kkt@kigam.re.kr
}

Received: October 3, 2019; accepted: November 17, 2019; first published online: August 17, 2020
Among the numerous analyses of SSDS, only a few ascribe them to intrastratal flow. This is understandable, because such a process requires specific conditions; these have been detailed first by Williams (1960), who mentioned that rapid deposition of silt and fine sand from sediment gravity flows can result in loose packing, a relatively high pore-fluid volume, and relatively low shear strength. Rapid loading of stratigraphically confined layers of loosely packed silt can induce mass flows and can reduce the original volume of the layer, resulting in increased neutral stress (pore-fluid) and decreased effective stress (grainto-grain contact). Liquefaction can occur if these become equal, at which point the buried intrastratal layer behaves as a concentrated suspension and flows downslope. Upon cessation of flow, the layer returns to solid state. This explanation by Williams (1960) is still accepted by recent researchers (e.g., Auchter et al., 2016), but they also make clear that only a combination of features can make it possible to ascribe deformations in a deformed layer to intrastratal flow.

We do so in the present contribution for some layers in the Cretaceous Gyeokpori Formation, which is exposed along the western coast of South Korea. The formation consists of lacustrine sediments that accumulated on the slope of a subaqueous fan-delta system, a position that is commonly considered most suitable to inducing and preserving SSDS (Gibert et al., 2005; Moretti and Sabato, 2007; Tanner and Lucas, 2007; Ko et al., 2015, 2017; Gladkov et al., 2016; Jiang et al., 2016). Indeed, the formation contains numerous SSDS in addition to those that 
we ascribe to intrastratal flow. The most frequent deformation structures are slump-related folds, sometimes forming "envelopes" of ductile fine-grained material deposited around more rigidly behaving gravelly parts (Byun et al., 2019).

\section{GEOLOGICAL SETTING}

During the Cretaceous, the Izanagi Plate was subducted along the eastern margin of eastern Asia (Chough and Sohn, 2010). At the same time, numerous non-marine sedimentary basins of different sizes were formed (Chough, 2013), including the lacustrine strike-slip Gyeokpori Basin on the present-day southwestern shore of the Korean Peninsula. Immediately west of the Gyeokpori Basin, a large $(\sim 20 \times 10 \mathrm{~km})$ volcanic body is present. The basin is filled with the lacustrine Gyeokpori Formation, the development of which was affected by the volcanic complex, informally known as the Buan Volcanics (Koh et al., 2013), in the form of eruption-induced earthquakes, lahar-derived hyperpycnites, and volcaniclastic layers.

The structures under study here were studied in a section located near the village of Jukmak along the western coast of Byeonsanbando National Park (Kim et al., 1995, 2003; Fig. 1). The Gyeokpori Formation is exposed here and in nearby sections in coastal cliffs and on wave-cut terraces. Palaeocurrent directions obtained from the geometry and dip direction of large sedimentary lobes, bed geometry, and sedimentary structures such as flute casts, current ripples, and gravel clusters, in combination with an analysis of the sedimentary facies, indicate that the sediments were deposited on a fan-delta on the southern margin of the basin; the delta prograded toward the north-northwest, while a fan-delta on the northern basin margin prograded toward the south-southwest (Kim et al., 2003). The depocentre of the basin must thus have been located in the western part of the basin, and the basin floor must have been gently inclined in the same direction.

\section{MATERIALS AND METHODOLOGY}

\section{LITHOLOGY, FACIES AND DEPOSITIONAL ENVIRONMENTS}

The Gyeokpori Formation is composed of conglomerates with clasts of various sizes, gravelly sandstones, mudstones, and abundant volcaniclastic deposits (Fig. 2).

Most of these are gravity-flow deposits formed by debris flows and turbidity currents (Kim et al., 2003). The total thickness of the formation is $\sim 290 \mathrm{~m}$. Ten sedimentary facies are distinguished. They have been detailed before (Byun et al., 2019) and the reader is referred to that study for details. The ten facies can be grouped into five associations (Byun et al., 2019), four of which represent subaqueous fan or fan-delta systems, and one the basin plain (Kim et al., 1995, 2003). A minor part of the sediments was deposited on the steep basin slope, but most accumulated on the basin plain in front of the lacustrine fan-deltas (Kim et al., 2003). Part of the layers deposited on the basin slope show chaotic soft-sediment deformations. These layers are the main subject of the present study.
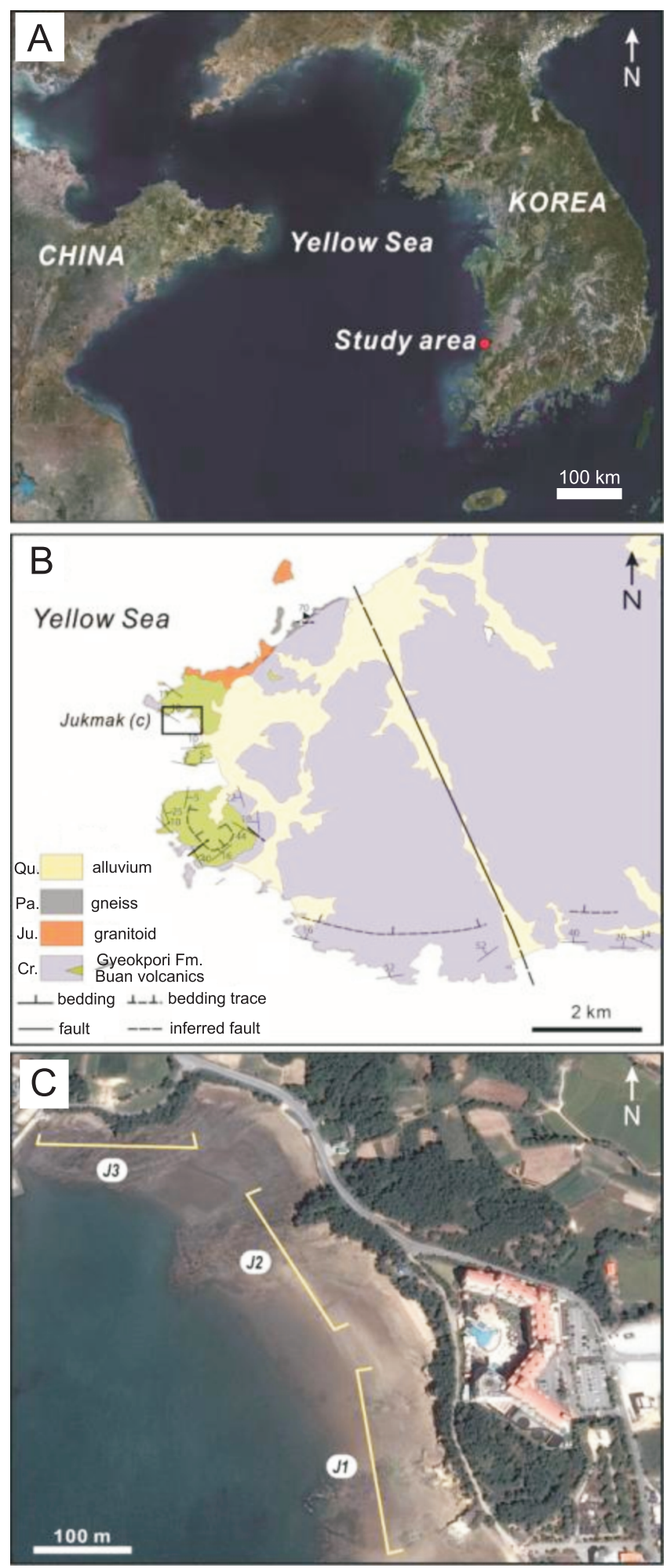

Fig. 1. Geographical and geological setting of the study area

A - location in southwestern South Korea; B - schematic geological map of the western margin of the mostly volcanic area of Byeonsanbando National Park (modified after Koh et al., 2013); C - aerial maps (from http://map.google.com) showing the location of the sections near Jukmak. Section J2 contains the layers affected by intrastratal flow 

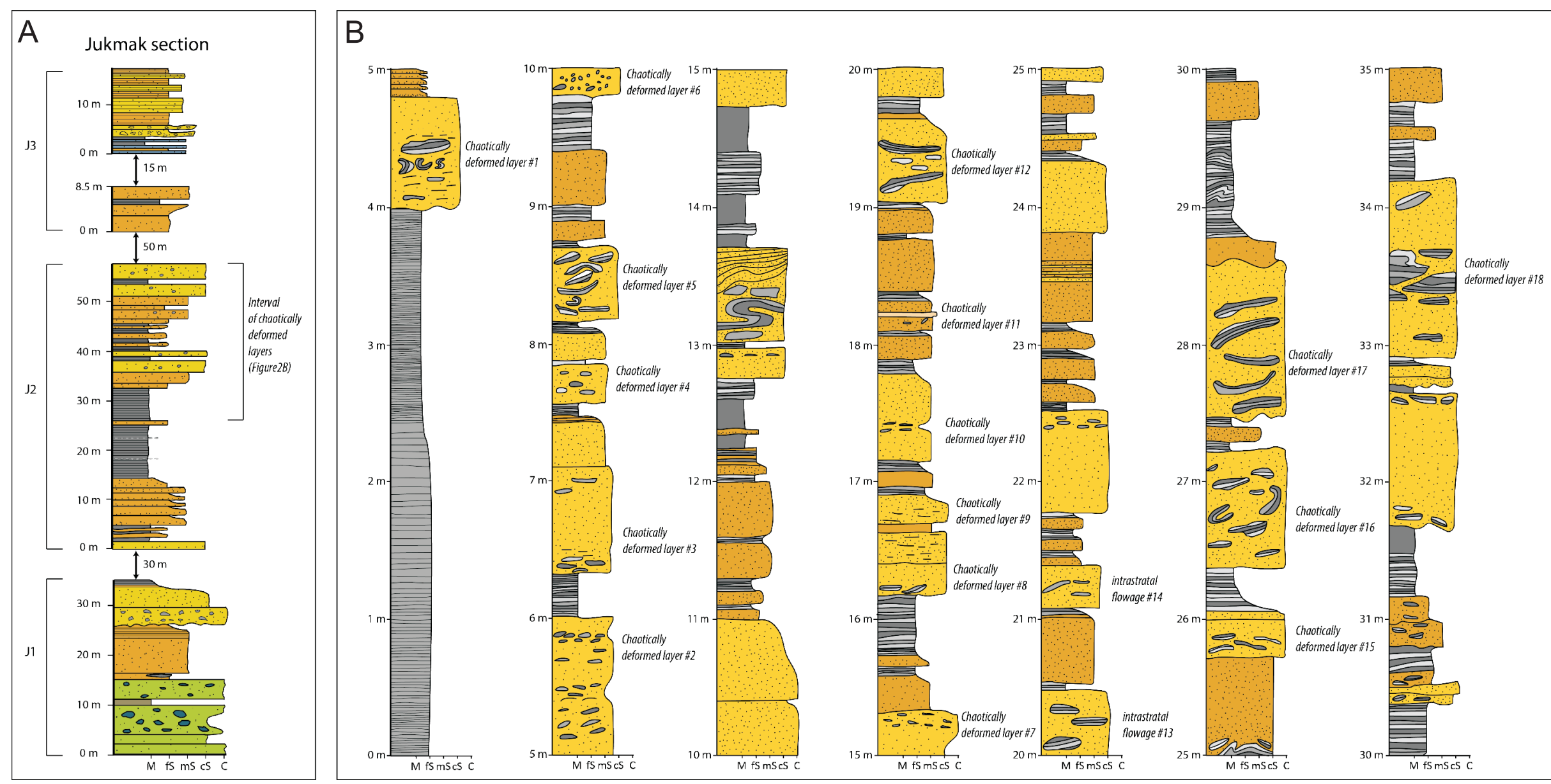

Fig. 2. Sedimentary succession of the Gyeokpori Formation

A - composite succession near Jukmak (see Fig. 1 for location of the sections J1, J2 and J3); B - sedimentary log of the interval with intrastratal flows (see A); in the entire succession at Jukmak, 18 chaotically deformed layers (CDL; this abbreviation is also used in the following figures) have been found and investigated; $\mathrm{M}$ - mud, fS - fine sand, $\mathrm{mS}$ - medium sand, $\mathrm{CS}$ - coarse sand, C - conglomerate 


\section{DESCRIPTION OF THE CHAOTICALLY DEFORMED LAYERS}

The chaotically deformed layers (CDL) that were deposited on the basin slope are each $<1 \mathrm{~m}$ thick. They occur in the upper part of the $\mathrm{J} 2$ exposure and in the lower part of the $\mathrm{J} 3$ exposure of the Jukmak section (Fig. 3). These layers (Figs. 4 and 5) occur intercalated between intraclast-rich sandstones that form part of a sandstone-dominated succession with relatively thin mudstone intercalations.

The layers under study are remarkable in themselves because of the - often chaotically - deformation within these layers, but also because of the uncommon characteristics of the clasts that are present in these layers. Both aspects will be detailed in the following sections, followed by a section devoted to the relationship between these two features.

\section{CHARACTERISTICS OF THE CDL}

The CDL have lower and upper boundaries parallel to the bedding planes of the other layers in the succession (Fig. 6), most of which do not show soft-sediment deformation structures or which show structures that are characteristic of sediment gravity flows such as slumps (with folds that indicate at least partially rotational deformation) as described and depicted by Byun et al. (2019).

The matrix of the CDL, which extend as far as the outcrop allows, consists mainly of clean medium to coarse sand without any grading or lamination (Fig. 7). Most layers are $0.3-1 \mathrm{~m}$ thick, and do not show significant lateral changes in thickness (Fig. 2). The upper and lower boundaries of the deformed layers are generally flat and sharp without any erosional features (Figs. 4-6).

\section{CHARACTERISTICS OF THE CLASTS}

The studied layers contain numerous laminated mudstone clasts (including rip-down clasts), which are lithologically and texturally identical to the laminated mudstones that are found in the sediments deposited on the middle part of the fan-delta (Fig. 7). The contacts between the clasts and the matrix are sharp (Fig. 8). These mudstone clasts are commonly deformed themselves in the form of bending (Fig. 9) or, more rarely, strong folding. The clasts do not show a gradual change in the intensity of deformation in either a horizontal or a vertical direction within one layer, but rather seem to show more or less random degrees of deformation. However, the CDL tend to have some specific horizontal levels in which clasts occur in larger concentrations than in other levels (see Figs. 7 and 8).

The shapes of the mudstone clasts vary from platy to slightly bent and they can even be strongly folded. Most of the platy clasts are elongated, with a preferred orientation more or less parallel to the bedding (Fig. 10). They have maximum visible sizes ranging from roughly 2 to $50 \mathrm{~cm}$, and elongated clasts commonly have angular outer ends (Fig. 11). The more folded or strongly bent clasts do not show a clearly preferred orientation, but a slight tendency exists (Fig. 12) that the convex parts of the bent clasts are orientated in the same direction. This is the downslope direction, roughly the same as the direction shown by the convex parts of the slump heads present in the Gyeokpori Formation.

\section{RELATIONSHIP BETWEEN THE DEFORMED LAYERS AND THE CLASTS}

The lithology of the mudstone clasts is very similar to that of the layered mudstones under- and overlying the layer; some of

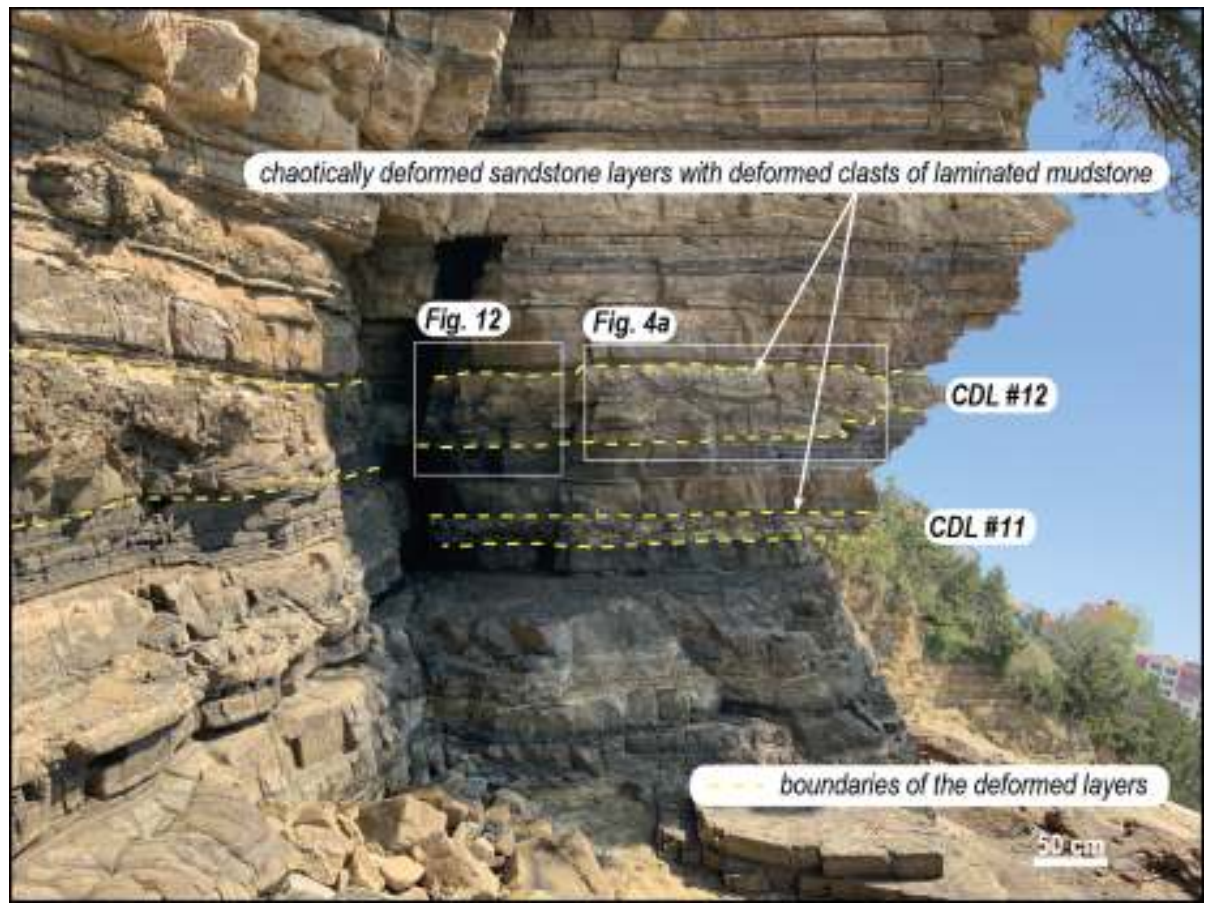

Fig. 3. The upper part of $\mathrm{J} 2$ in the Jukmak section with several layers deformed by intrastratal flow 

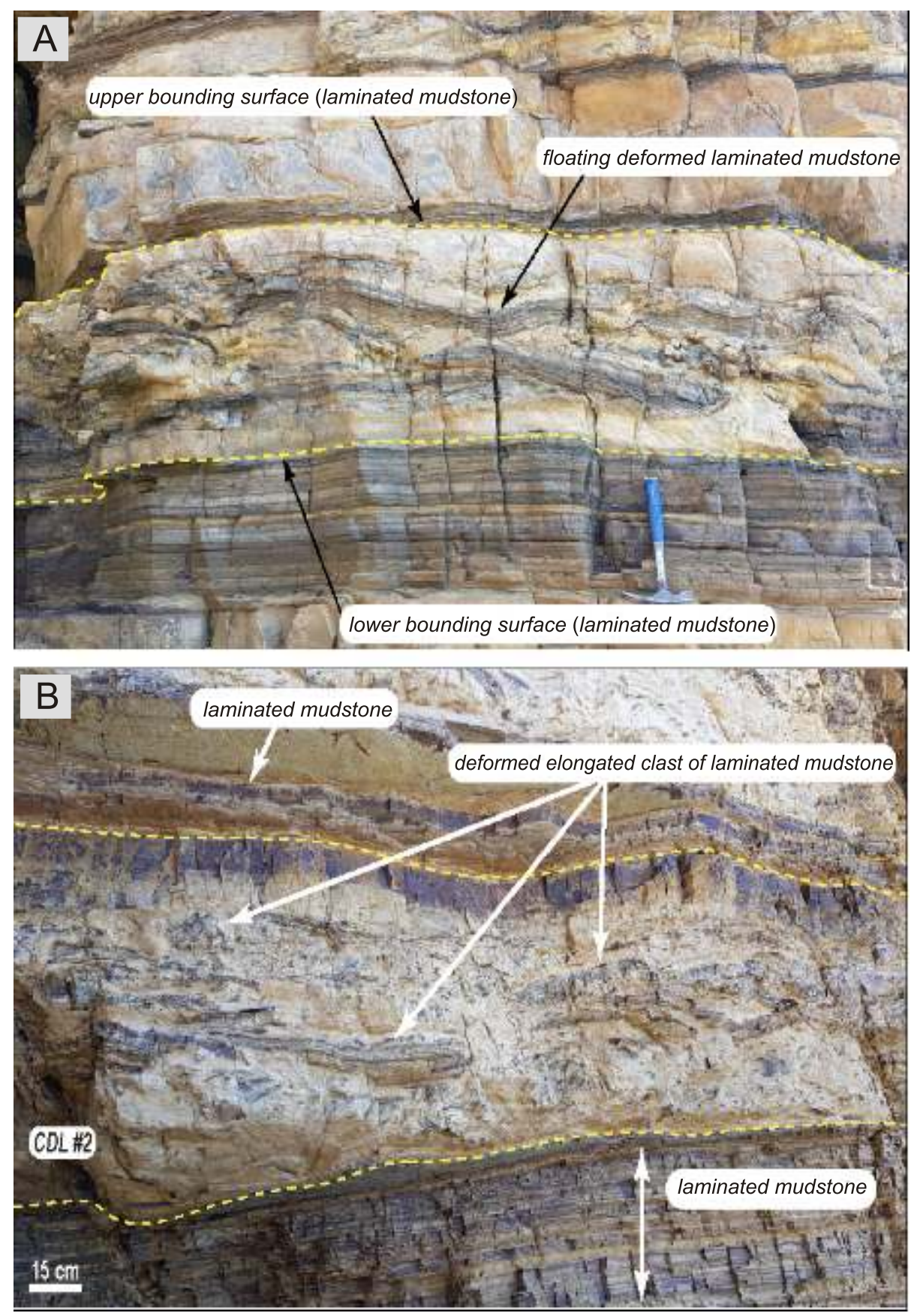

Fig. 4. Details of some layers affected by intrastratal flow

A - example of a layer with long and slightly deformed floating clasts of laminated mudstone; B - example of a layer with numerous smaller clasts of floating laminated mudstone

the clasts are still partly connected with the overlying mudstone layer (Fig. 7), but never with the underlying mudstone layer. The mudstone clasts in the deformed layers must consequently be derived from the partly broken-up overlying consolidated mud layers or comparable thin and broken-up mudstone layers that occur in most of the top parts of the deformed layers (Fig. 13), whereas isolated fragments occur near both the upper and the lower boundaries (Fig. 14).

\section{INTERPRETATION OF THE CHAOTICALLY DEFORMED LAYERS AND THEIR CHARACTERISTICS}

The most remarkable features in the CDL are the deformed mudstone clasts that float in the sandstone matrix. They must have resulted from soft-sediment deformation that eventually 


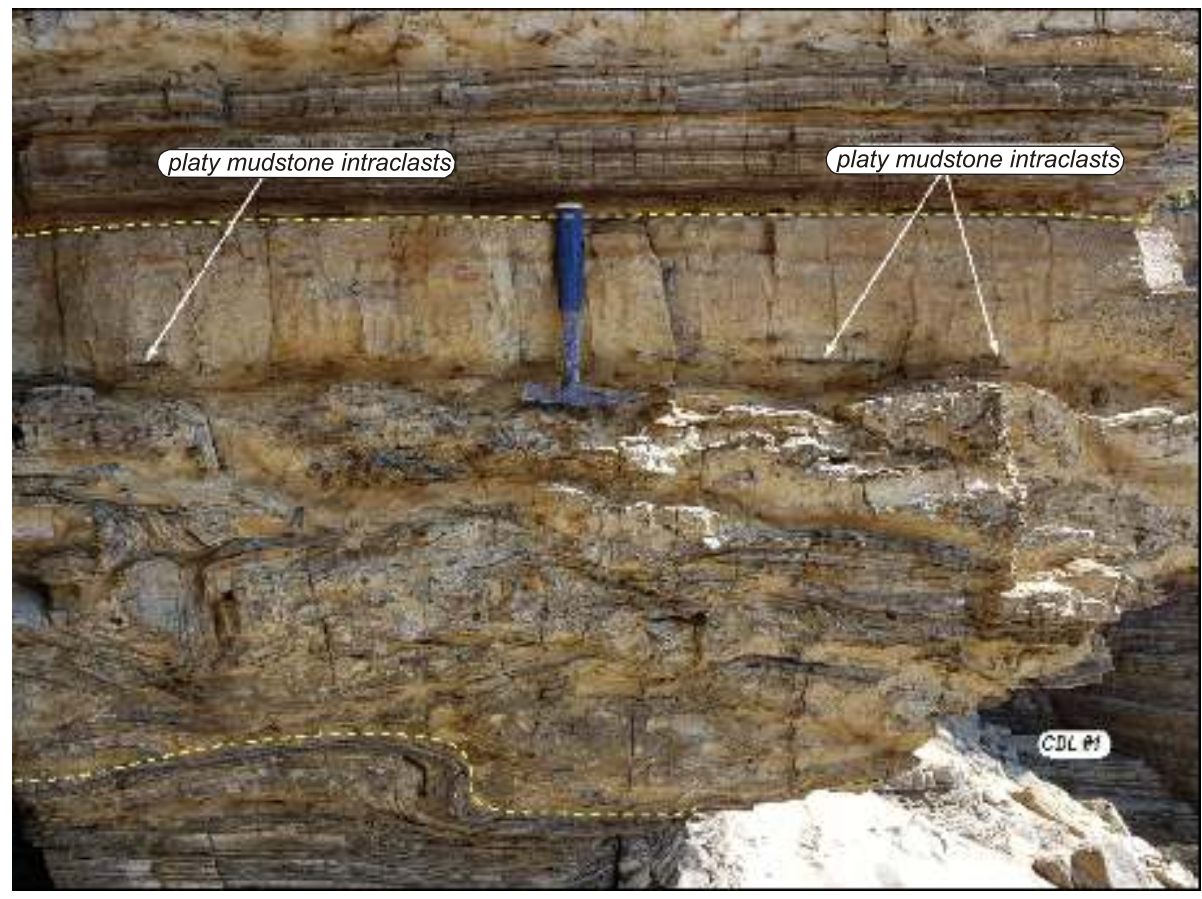

Fig. 5. Detail of chaotic soft-sediment deformation structures in one of the layers affected by intrastratal flow

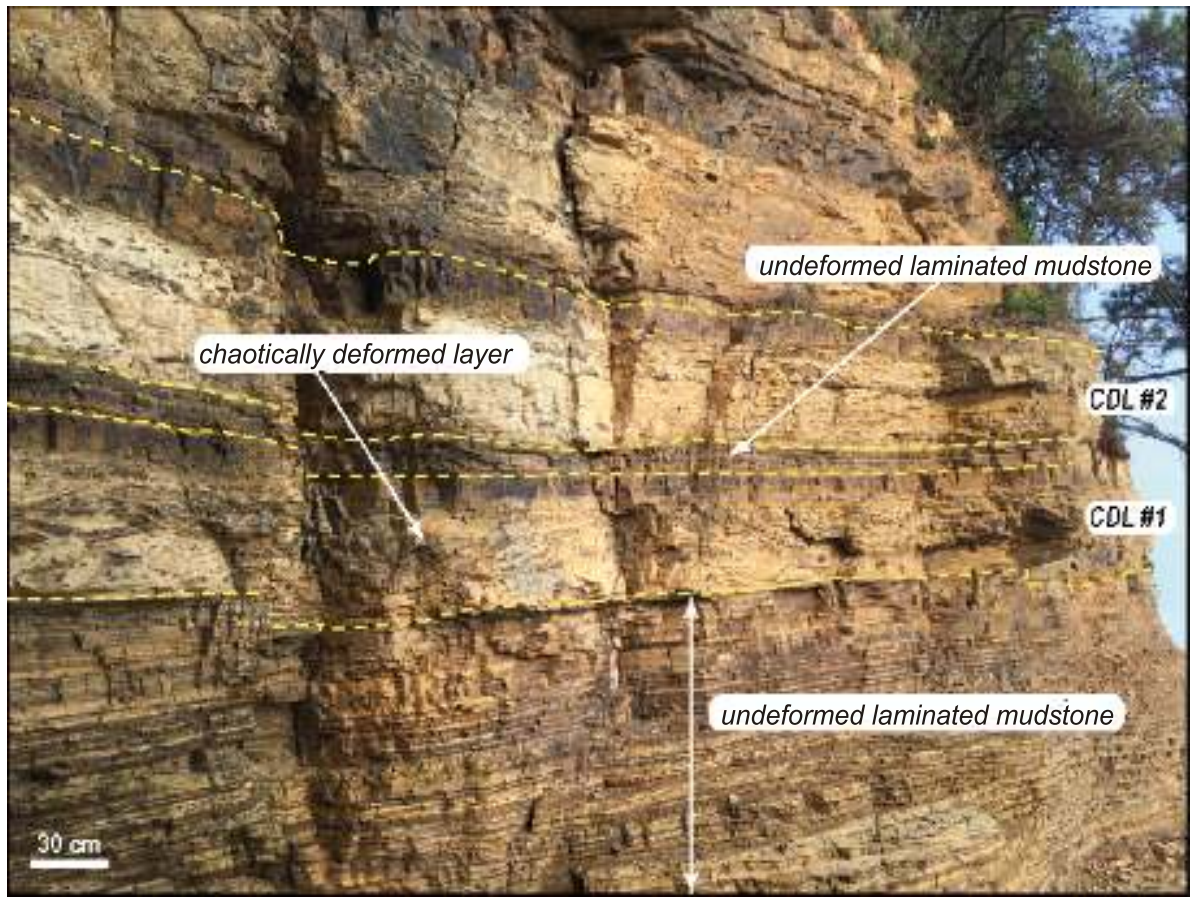

Fig. 6. Deformed layer affected by intrastratal flow intercalated between two undeformed layers, showing parallel, relatively undeformed lower and upper boundaries

resulted in fragmentation of one or more thin mud layers. This can be deduced from the fact that the clasts show the same lamination as the broken-up mudstone layers (Fig. 15). Their breaking-up points to the presence of an impermeable layer that led to a high pore pressure in the sand under the influence of a thickening overburden.
Liquefaction occurred when the threshold value of the shear stress was passed, resulting in intrastratal flow. Once the sand layer liquefied, it flowed along the slope and broke up the mud layer above and/or below it (or both); this explains the relatively high concentration of clasts in the upper and lower parts of the deformed layers. The fragmentation process caused by the liq- 


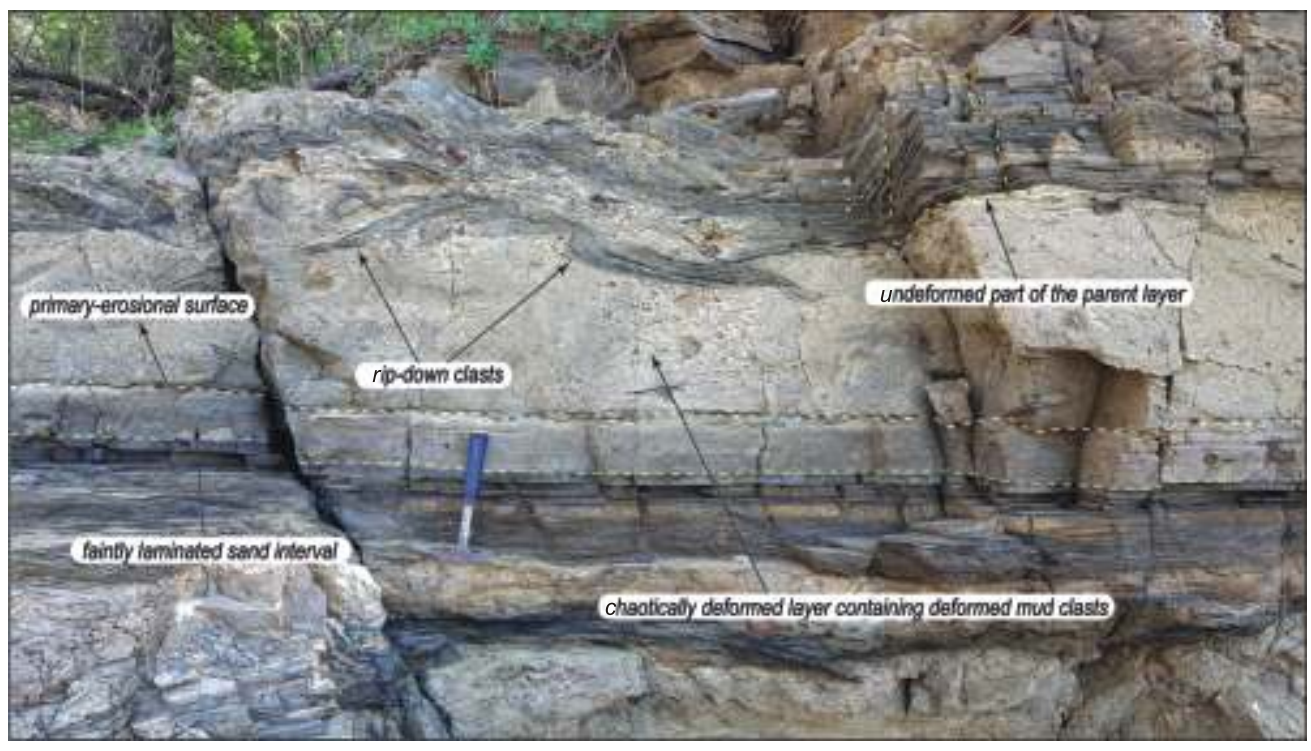

Fig. 7. Large mudstone clasts in a deformed sandstone layer still partly adhered to their broken-up parent mudstone layer

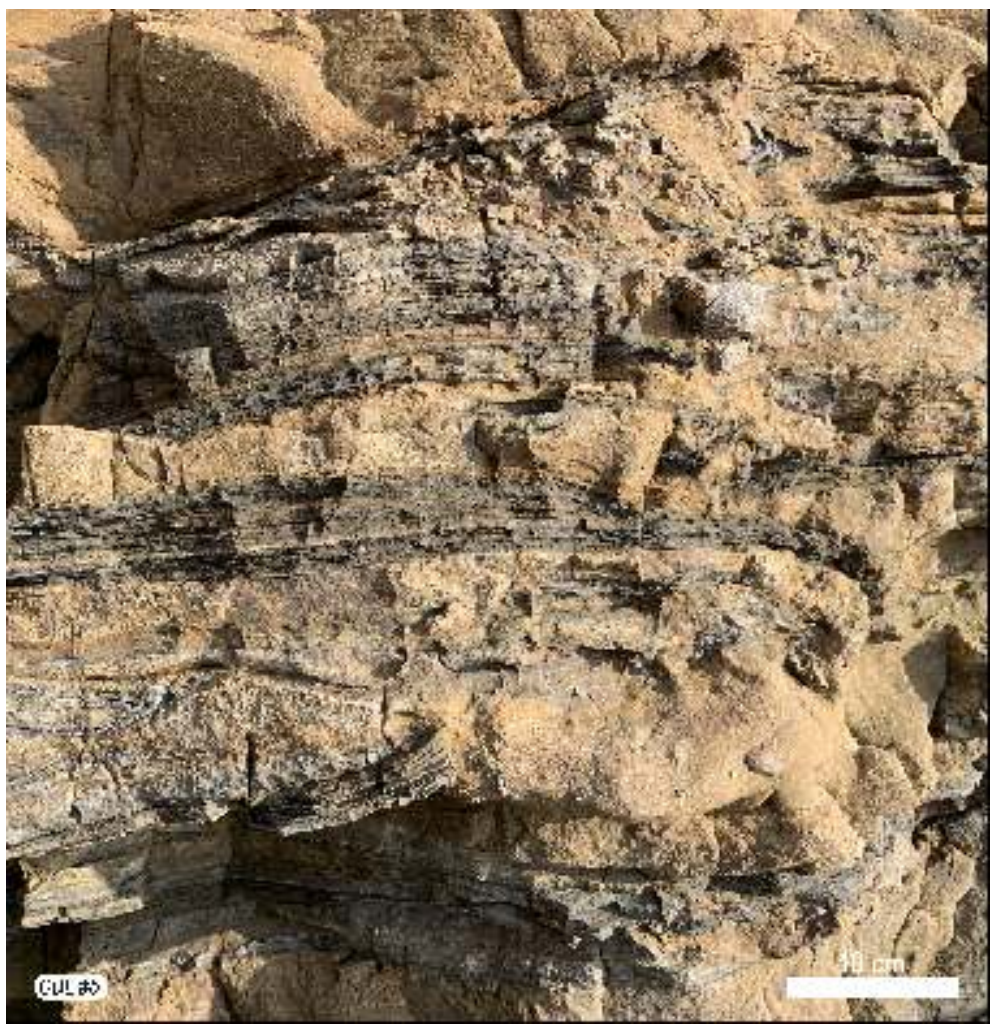

Fig. 8. Detail of clasts of laminated mudstone within the sand of a layer affected by intrastratal flow

Note the sharp contacts between the clasts and the matrix

uefied intrastratal flow was possibly due to the cohesive character of the already consolidated muddy material. The same argumentation was used by Chough and Chun (1988) and Kawakami and Kawamura (2002) for the explanation of the mudstone clasts mentioned in the above description section; they also arrived at the conclusion of intrastratal flow.
Facies analyses by previous researchers (Kim et al., 2003; Koh et al., 2013), as well as our analysis of other SSDS in the Gyeokpori Formation (see Byun et al., 2019), convincingly demonstrate that these successions were almost all deposited by sediment gravity flows on the inclined slope of a lacustrine deltaic fan. This strongly suggests that the originally accumulated sandy layers were deposited at a high sedimentation rate, 


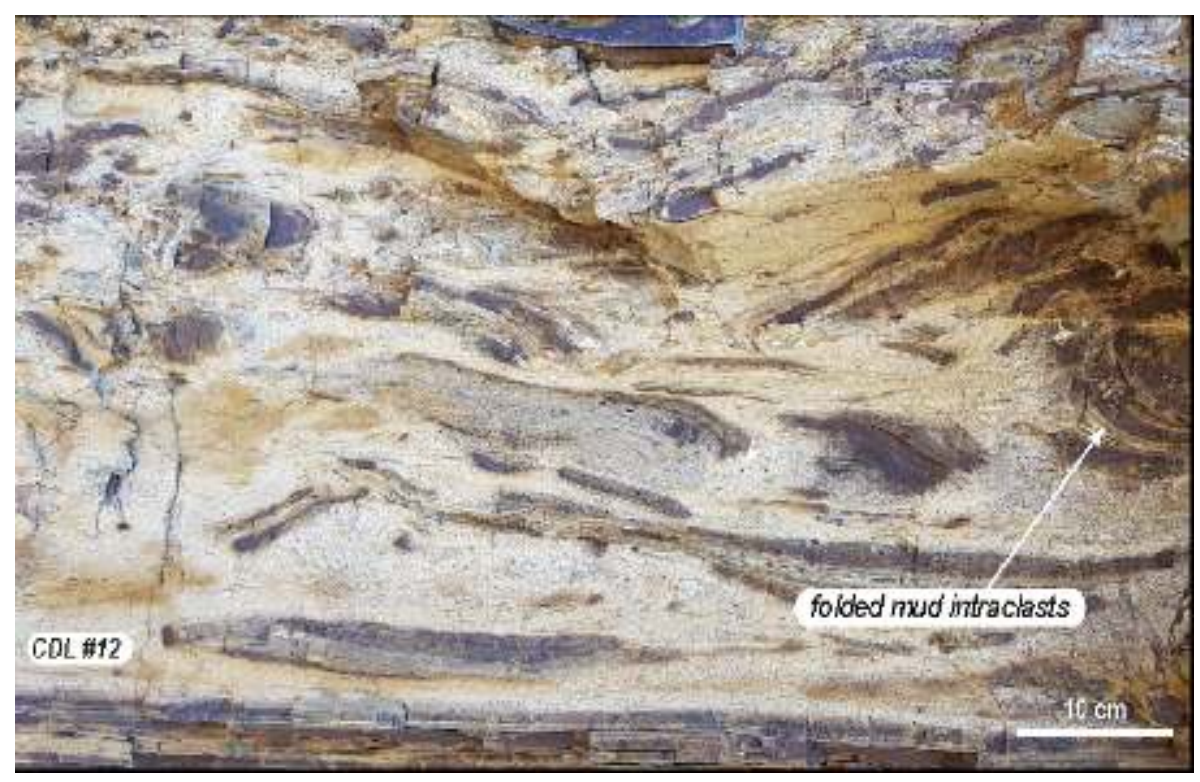

Fig. 9. Detail of deformed (slightly bent to strongly folded) intraclasts of laminated mudstone in a sand layer affected by intrastratal flow
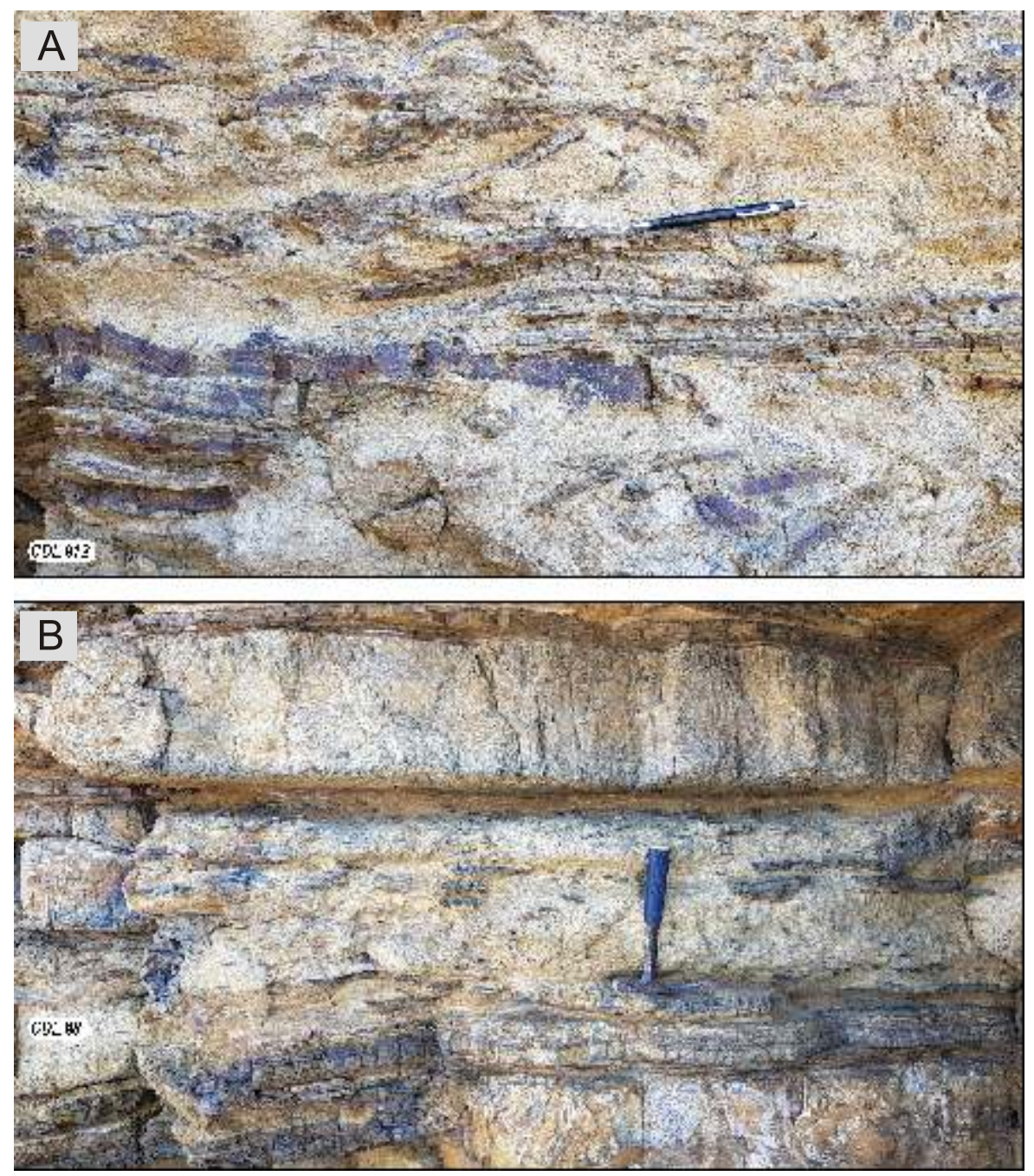

Fig. 10. Platy clasts of laminated mudstone preferentially orientated (sub)parallel to the bedding

A - detail of the (sub)parallel orientation of the clasts within a layer; $\mathbf{B}$ - overview of (sub)parallel clasts near the contact with the under- and overlying layers 


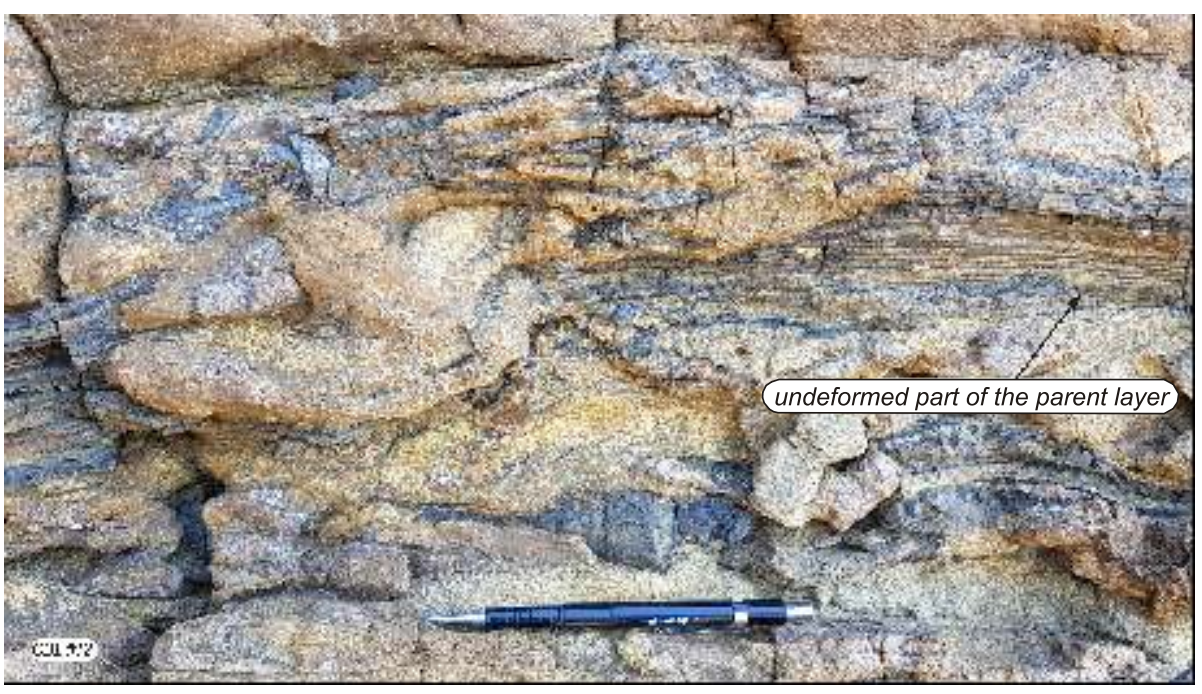

Fig. 11. Clasts of different sizes

Note the angular outer ends indicating that no traction transport has taken place

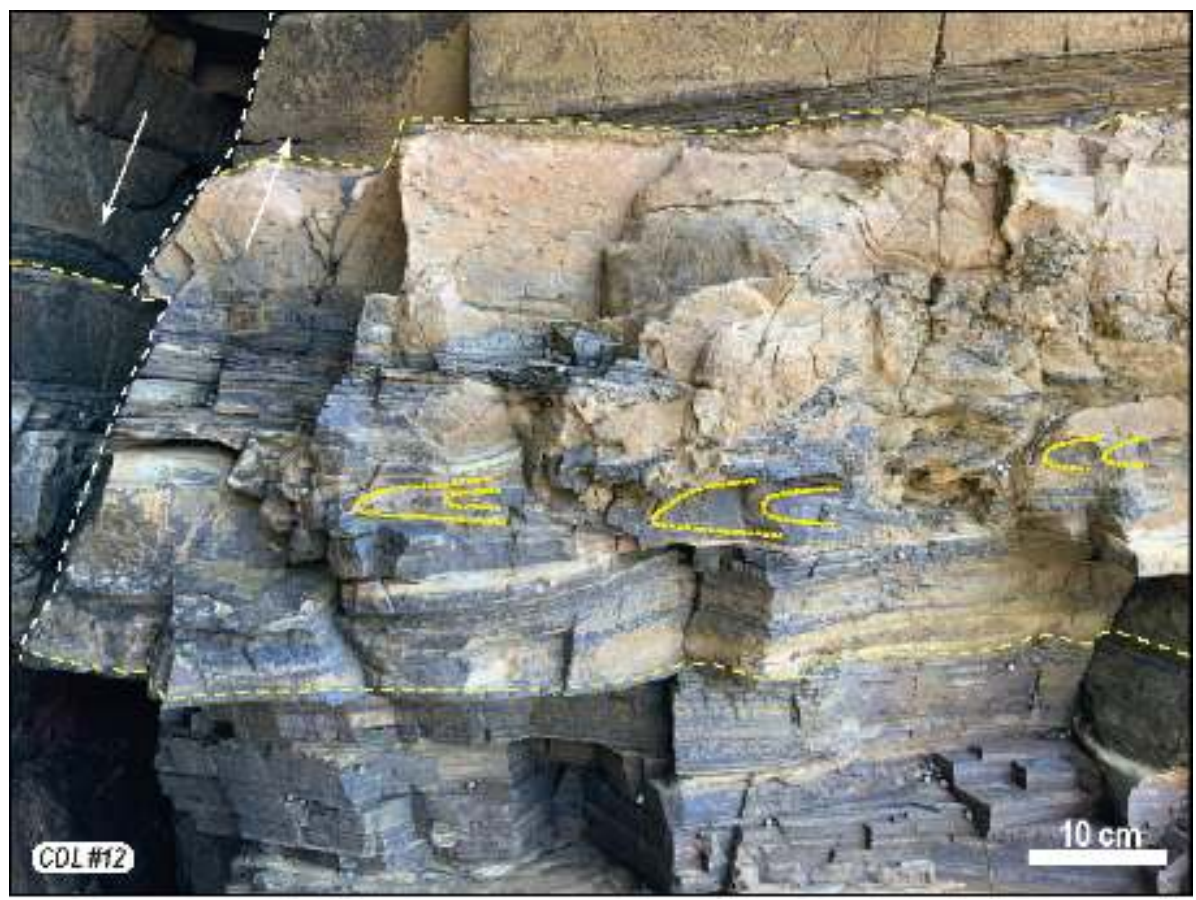

Fig. 12. Deformed mudstone clasts showing a slight tendency to have their convex side orientated in the same direction, resembling the bending of a slump head with the convex side downslope, thus indicating the direction of the flow

The yellow dashed lines represent the boundaries of the deformed layer, whereas the white dashed line indicates a fault

under which conditions the sediments, after having become buried under new sediment, were likely to contain much pore water. The silty/clayey layers accumulating above the sandy deposits must have been relatively impermeable, thus forming a sealing layer, preventing the pore water in the sands to seep out gradually.
Considering the largely gravity-driven depositional process on the slope, the sealing sediments became covered by new gravity-flow deposits intermittently but frequently (Fig. 16A), so that the already high pore pressure in the sandy layers below the sealing mud became ever higher (Fig. 16B). These alternating beds made the sediments easily susceptible to liquefaction 



Fig. 13. Comparison of the mudstone clasts and the mudstone deposited on the middle part of the fan-delta

A - autochthonous laminated mudstone;

B - characteristic mudstone clast in a sandstone layer affected by intrastratal flow

and fluidization, which processes may well have been triggered by endogenic processes (e.g., seismic waves resulting from nearby volcanic eruptions; Fig. 16C, D). The liquefied water-saturated sediments flowed downslope within a confined pathway between the more cohesive layers that did not liquefy (Fig. 16D). At the beginning of this flow, the sediments flowed down intrastratally, while impermeable, more consolidated mud layers below and above acted as bounding layers (Fig. 16D).
During a subsequent stage, more layers of liquefied and fluidized sand started to move downslope intrastratally, eventually breaking up an impermeable mud layer between the two flowing masses of liquefied sand with mudstone clasts that continued to move downslope (Fig. 16E); when the slope became too gentle, the sediments stopped, thus forming layers with deformed mud clasts (Fig. 16F). 


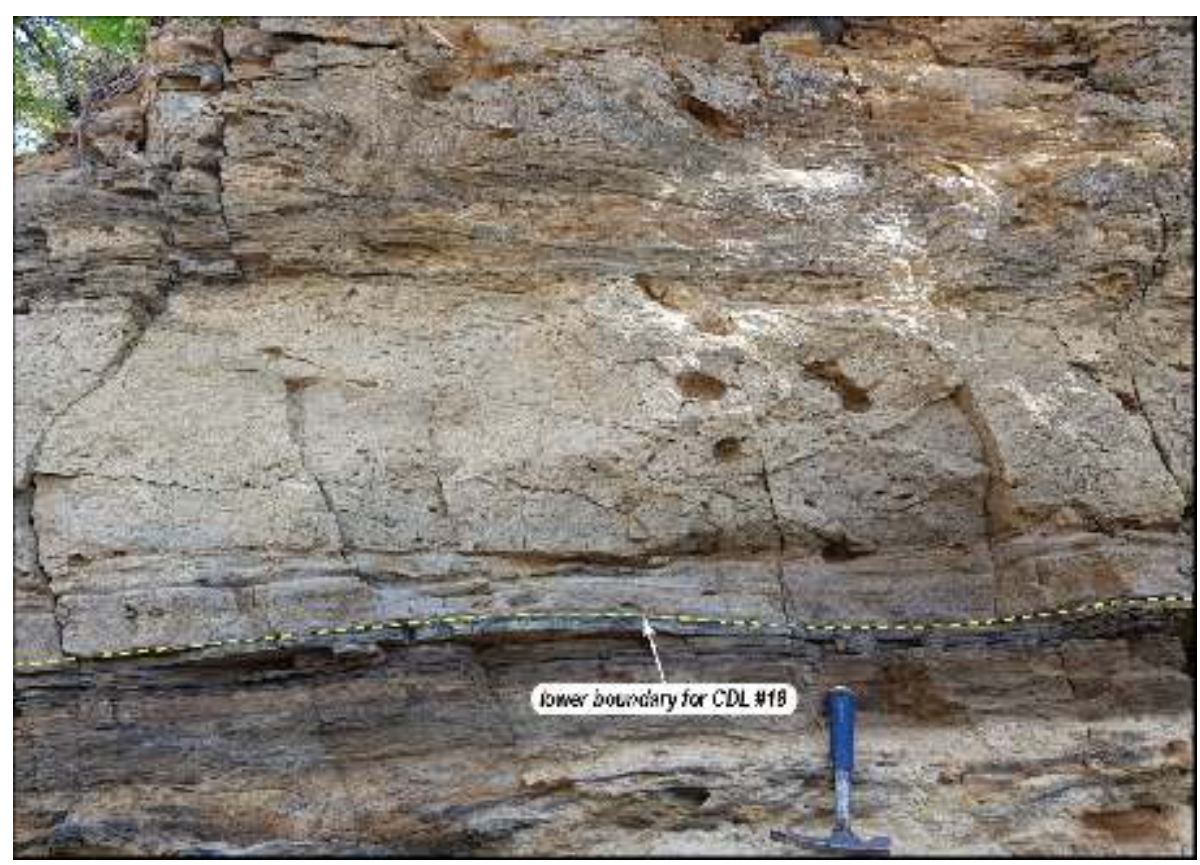

Fig. 14. Concentration of mudstone clasts in a sandstone layer near the mudstone levels below and above

\section{DISCUSSION}

As descriptions of intrastratal flow are rare in the literature, and because the process of intrastratal flow is still poorly understood, it is appropriate to investigate why other processes could not have resulted in the CDL described above. Post-depositionally deformed layers intercalated between undeformed layers formed subaqueously have most commonly been interpreted to have resulted from gravity flows (particularly slumps and turbidity currents), from dragging by (mostly sediment-laden) currents, and from seismic shock waves.

\section{COMPARISON \\ WITH GRAVITY-FLOW DEPOSITS}

Gravity-flow deposits that show frequent deformations mainly consist of slumps, cohesive mudflows, and turbidites (e.g., Haughton et al., 2003; Alsop and Marco, 2013). All of these can consist of sandy material with mud clasts, but the characteristics of such deposits differ fundamentally from those under study here.

Slumps occur abundantly in the Gyeokpori Formation, commonly as sets of alternating sandy and fine-grained turbidites. However, these layers were deformed differently because of the difference in cohesion that resulted in brittle behavior of the consolidated sands and in plastic behavior of the muds. The processes involved and the resulting deformations have been described in detail by Byun et al. (2019). Consequently, the muddy layers were bent (sometimes locally chaotically because of the space problem created during the rotational movement of the slumping mass), whereas the more sandy layers were commonly broken up into larger or smaller fragments, depending on their precise place in the slump (see Byun et al., 2019). The primary lamination (and sometimes also current ripples) in the slumped sandy turbidites remained well-preserved as a rule.
These characteristics are fundamentally different from the CDL under study here, where no primary structures are preserved in the sandstones, where the sandstone is not broken up into small fragments, and where the muddy layers have been broken up into small fragments. Consequently, the distortions in the CDL in question cannot be attributed to slumping.

Mudflows can, if their downslope movement takes place relatively quietly, preserve fragments with primary structures if the flow is sufficiently cohesive. However, this requires a high amount of silt and/or clay (as already indicated by the term "mudflow"), but the layers under study mainly consist of fairly clean sandstone. Moreover, transport within a mudflow that was able to break up consolidated mud layers should have resulted in some rounding of the mud clasts (see, for instance, Pisarska-Jamroźy et al., 2019), but these are angular. Further, if both consolidated sand and mud layers had been involved in the mudflow, not only mud clasts but also sandy clasts should be present. For all these reasons, an origin as mudflow deposits can also be excluded.

Turbidites can contain a level (the $T_{c}$ division of Bouma) that is strongly deformed. The Gyeokpori Formation does contain numerous turbidites, indeed, but these show the "classical" characteristics (though mostly incomplete) of Bouma divisions, including convolutions, sole marks, and grading. Moreover, these sandy turbidites show abundant primary structures, while the CDL have none of these characteristics and therefore cannot be ascribed to deposition by turbidity currents.

Considering the above fundamental differences between the CDL and slumps, mudflow deposits and turbidites, we must conclude that the sediments under study cannot be considered as slumps, debrites, turbidites or any other form of mass-flow deposit.

Another problem to be solved is the question whether the deformed layers can have been deposited before the overlying sediments were deposited. Such a situation would imply liquefaction of the uppermost sedimentary succession of thin mud, 

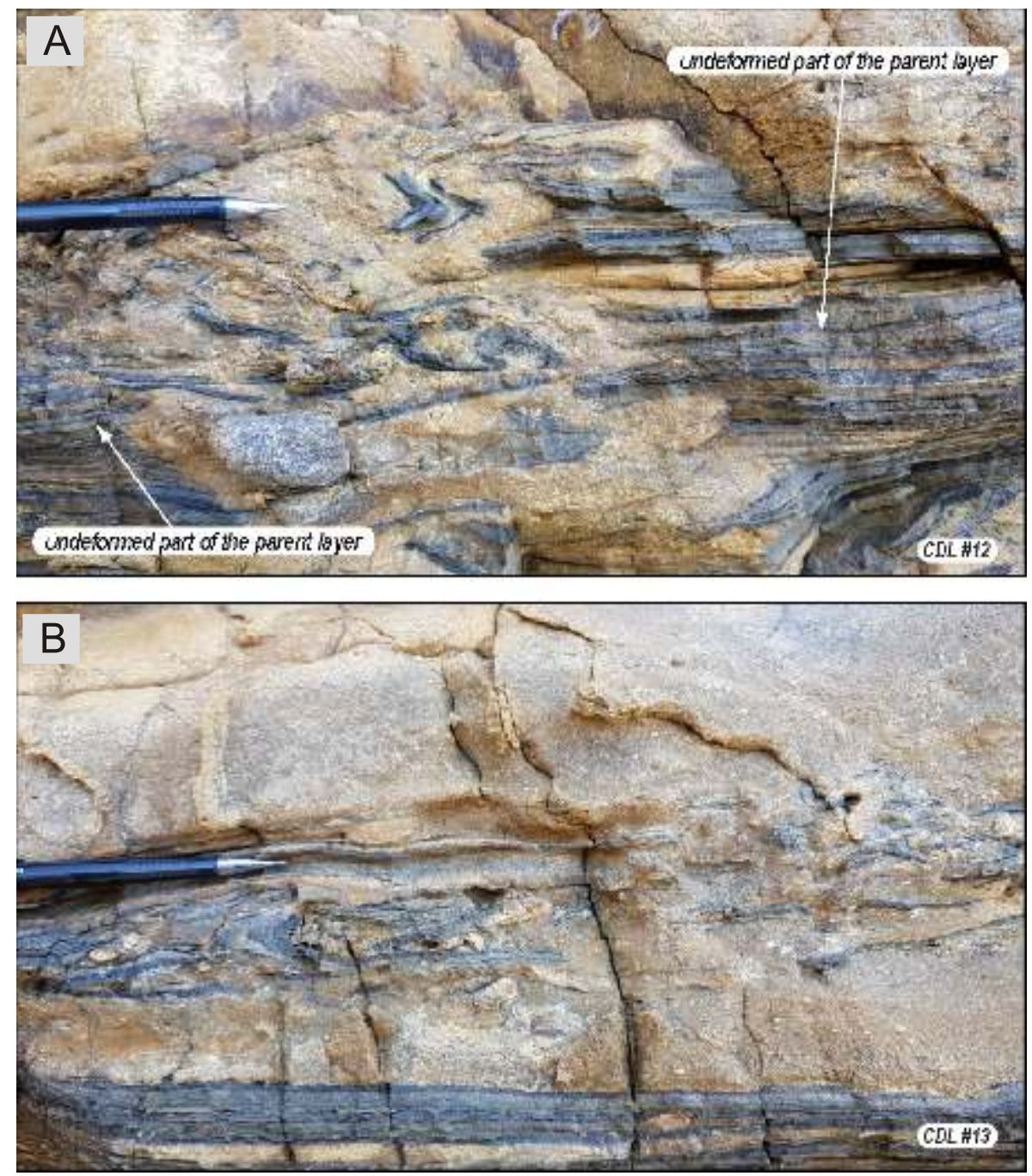

Fig. 15. Similarity of the broken-up laminated mudstones and the mudstone clasts

A - detail of broken-up autochthonous laminated mudstone in a deformed layer; B - detail of a clast of laminated mudstone in the same sandstone layer

sand and mud. If such a sedimentary unit would start moving downslope (which must, considering the position and orientation of the mudstone clasts, have taken place), breaking up of the mud layers can have occurred only if they had already been consolidated. Such a consolidation is highly unlikely, however, because of the high sedimentation rate: consolidation would have required too much time. An even more convincing argument against subaqueous rather than intrastratal flow is that subaqueous flow must have taken place in some form of gravity flow (slump, debris flow, turbidite). The CDL, however, does not show the characteristics that belong to one of these types of gravity flow, which implies that gravity flowage without a sedimentary cover must be excluded.

\section{COMPARISON WITH DRAG STRUCTURES}

Although relatively rare, numerous sandstone layers with fairly extensive deformation caused by dragging have been described in the literature (e.g., Rana et al., 2016). Such dragging tends to be caused by shear stress exerted on the slightly consolidated sandy surface layer due to the movement of some mass. The mechanism involved is commonly a sediment-laden bottom current but can also be something different, such as ice (e.g., Curran, 2007; Frey and Dashtgard, 2012; Salamon, 2015; Mazumder et al., 2016; Rana et al., 2016). However, such dragging results in the bending of foresets (if present) in a regular (not chaotic) way, so the CDL under study cannot be attributed to this process.

\section{COMPARISON WITH SEISMITES}

Earthquakes with a magnitude of over $4.5-5$ produce shock waves with an intensity that can cause deformation of specific near-surface layers (occasionally a set of layers); such deformed beds are called seismites. These layers can be sandy or finer-grained, or consist of alternations of finer and coarser material. Their characteristics have been described in numerous studies, including examples in which fragmented material of broken up layers is present (e.g., Van Loon et al., 2016).

Although no traces of tectonic activity during the accumulation of the Gyeokpori Formation are known, extensive volcanic activity did take place (Kwon et al., 2017). This must have been 


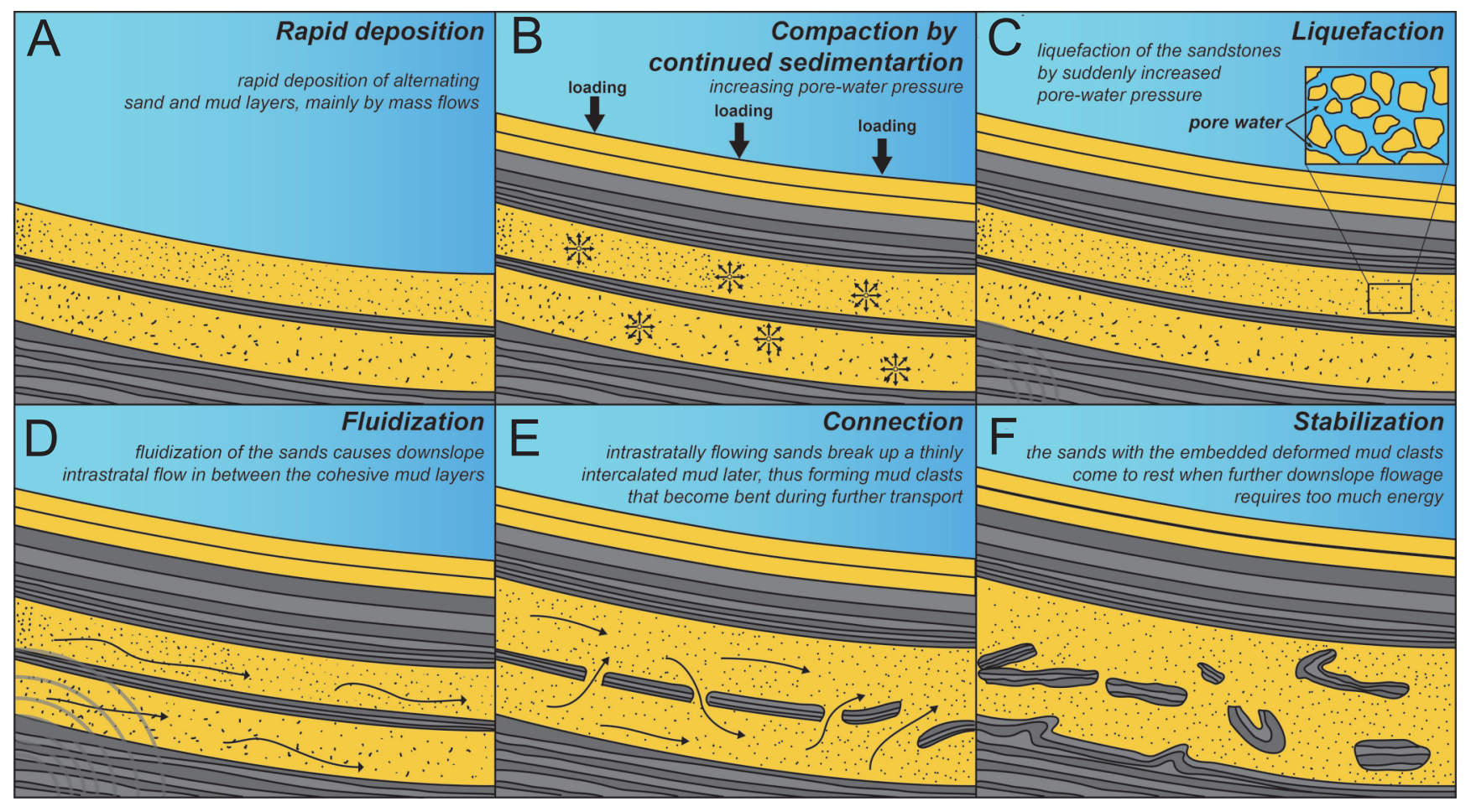

Fig. 16. Schematic model of the development of intrastratal flow

A - high sedimentation rate results in a succession of alternating sandy and muddy water-saturated sediments; $\mathbf{B}$ - compaction under the influence of a thickening overburden results in increased pore-water pressure; $\mathbf{C}$ - some process (here probably a seismic shock related to nearby volcanic activity) results in liquefaction of two sandy layers between still-cohesive mud layers; D - two sandy layers become fluidized and the sand/water mixtures start to flow downslope; $\mathbf{E}$ - two intrastratally flowing layers break up the thin mud layer in between them and sand fragments of the mud layer become embedded in the flow; $\mathbf{F}$ - mud fragments become deformed during flow, and the deformed mud clasts remain embedded in the homogenized sand when the intrastratal flow comes to rest

accompanied by earthquakes, some of which could certainly have had a sufficiently high magnitude to trigger the formation of seismites. Indeed, some seismites are known in the formation, but their characteristics are (like most seismites described in the literature), completely different from those of the layers under study here. If both sandy and silty material is involved in seismic deformation, the first process taking place is loading, often accompanied by small-scale faulting. This deformation process is restricted to the layer (or the set of layers) through which the seismic wave (commonly a Raleigh wave) travels; the under- and overlying layers remain undeformed. In the Gyeokpori Formation, however, there is no such well-defined level of deformation (Fig. 16F). Moreover, seismites tend to contain load casts that were themselves deformed again by aftershocks. None of these characteristics are present in the layers under study, so a seismic origin for the deformations must be excluded.

\section{ARGUMENTS}

\section{IN FAVOUR OF INTRASTRATAL FLOW}

Some structures that have been preserved in the CDL (rip-down clasts, some folds, and partial fluidization) have, as will be detailed below, been described earlier from sediments that underwent intrastratal flow. One more such characteristic is that the intrastratally deformed layers have a partially liquefied part near their lower boundary, which has resulted in semi-detached clasts near the top of the underlying laminated mudstone layer. It is noteworthy that the characteristics of the mudstone clasts show many similarities with the clasts (called "rip-down clasts") described by Chough and Chun (1988): "The clasts include small, fibrous shale chips and large disc forms (0.5-65 cm long and $0.1 \mathrm{~mm} 8 \mathrm{~cm}$ thick). The existence of large, semidetached clasts in the upper part suggests that they were derived from the overlying bed rather than the underlying bed." They also show similarities with the clasts in deformed layers described by Kawakami and Kawamura (2002): "Closely packed sheet-form or ellipsoidal mud clasts are embedded in a poorly sorted fine- to coarse-grained sandy matrix. Some mud clasts are tightly folded, or show imbricated stacking". Similar features have also been ascribed to intrastratal flow by Whitmore and Strom (2010).

Rip-down clasts with comparable characteristics have also earlier been reported from lacustrine sediments, where they have been interpreted as the result of intrastratal flow (Chough and Chun, 1988; Chun and Chough, 1992). These studies also considered this as strong evidence for intrastratal flow because platy mud clasts with sharp edges cannot result from wave-induced scouring without resulting in an erosional surface, normal grading by settling of fines stirred up by waves, and hummocky cross-stratification. No such features are present in the layers under study. Moreover, the mudstone clasts must have been derived from the overlying laminated mudstone layer because some large clasts are still partly attached to this overlying layer (Fig. 7).

The folding of the underlying mudstone bed (Fig. 16F) is additional evidence for intrastratal flow. Such folds can only be as- 
cribed to plastic deformation resulting from shear at the bottom boundary. The extensive shearing and fragmentation of the laminated mudstone suggest that the mud was subjected to penecontemporaneous deformation with liquefaction and subsequent intrastratal flow. If the folding of the underlying layer would represent slumping, a more or less undulating surface would have been formed, and this would have been easily truncated by a following gravity flow. Considering that such an erosional surface is absent, the folding of the underlying mudstone bed can only be due to intrastratal flow in a liquefied state. This process thus differs from liquefaction in water-saturated, cohesionless silts and fine sands where the liquefaction results in the loss of strength, but not in folding. The underlying shale bed thus was partially affected by the flow, as proven by the fold structures and the partially detached mudstone layers.

\section{FLOW DIRECTION}

One of the important questions concerning presumed intrastratal flow is whether there was a slope, and - if so - whether it can be determined that the flow took place in downslope direction. The first question can be answered easily: as all facies analyses (e.g., Kim et al., 1995, 2003) indicate that the sediments under study were deposited on the middle part of a fan-delta, a slope must have been present. Both the lower and upper boundaries of the beds under study are parallel to the bedding of all other layers, and this must represent the inclined sedimentary surface. A slope is also evidenced by the presence of numerous slumps.

An important question is, obviously, in which direction the intrastratal transport took place. This could not be established directly from the CDL, because they do not show any features that provide unambiguous information. However, the bending of the clasts shows, as indicated above, a roughly identical orientation as the bent heads of most of the slumps. For this reason we will pay here some attention to the flow directions found by measuring the folds and fold axes of the slumps in the formation.
The Jukmak slump data show a smallest interlimb angle in the $275^{\circ}$ fold hinge azimuth, and fold tightening tends to increase along the $275^{\circ}$ trend supporting that this is the slump direction. Considering the similarity in the orientation of the bent mudstone clasts in the CDL and the orientation of the slump heads, it must be considered highly probable that the intrastratal flow was directed downslope, i.e. toward $275^{\circ}$.

\section{CONCLUSIONS}

Chaotically deformed sandstone layers are present in the Cretaceous Gyeokpori Formation. They contain floating intraformational mudstone clasts that are also deformed. The characteristics of these sandstones can be explained satisfactorily only by intrastratal flow. Two sandy layers, separated by a mud layer, became liquefied and started to flow downslope intrastratally. They broke up the mud layer in between, and the fragments of this mud layer became embedded in the flow. The mud fragments became deformed during the flow, and the deformed clasts remained embedded in the homogenized sand when the intrastratal flow came to rest. This reconstruction shows that the nature of the sediments (muddy or sandy) and particularly their combination (thick or thin layers) plays an important role in intrastratal flow.

Acknowledgements. This work was supported as a Basic Research Project (GP2020-003; Geological survey in the Korean Peninsula and publication of the geological maps) of the Korea Institute of Geoscience and Mineral Resources (KIGAM), funded by the Ministry of Science, ICT (Information, Communication and Technology), and Future Planning, Korea. We thank the reviewers, G. Kawakami and an anonymous reviewer, for numerous suggestions that helped improve both the explanation of the scientific processes involved and the information presented in the photographs.

\section{REFERENCES}

Alfaro, P., Moretti, M., Soria, J.M., 1997. Soft-sediment deformation structures induced by earthquakes (seismites) in Pliocene lacustrine deposits (Guadix-Baza Basin, central Betic Cordillera). Eclogae Geologicae Helvetiae, 90: 531-540.

Alsop, G.I., Marco, S., 2013. Seismogenic slump folds formed by gravity-driven tectonics down a negligible subaqueous slope. Tectonophysics, 605: 48-69.

Auchter, N.C., Romans, B.W., Hubbard, S.M., 2016. Influence of deposit architecture on intrastratal deformation, slope deposits of the Tres Pasos Formation, Chile. Sedimentary Geology, 341: $13-26$.

Byun, U.H., Van Loon, Kwon, Y.K., Ko, K., 2019. A new type of slumping-induced soft-sediment deformation structure: the envelope structure. Geologos, 25: 111-124.

Chough, S.K., 2013. Geology and Sedimentology of the Korean Peninsula. Elsevier, Amsterdam.

Chough, S.K., Chun, S.S., 1988. Intrastratal rip-down clasts, Late Cretaceous Uhangri Formation, southwest Korea. Journal of Sedimentary Petrology, 58: 530-533.

Chough, S.K., Sohn, Y.K., 2010. Tectonic and sedimentary evolution of a Cretaceous continental arc-backarc system in the Ko- rean Peninsula: new view. Earth-Science Reviews, 101: 225-249.

Chun, S.S., Chough, S.K., 1992. Depositional sequences from high-concentration turbidity currents, Cretaceous Uhangri Formation (SW Korea). Sedimentary Geology, 77: 225-233.

Curran, J.C., 2007. The decrease in shear stress and increase in transport rates subsequent to an increase in sand supply to a gravel-bed channel. Sedimentary Geology, 202: 572-580.

Debacker, T.N., Dumon, M., Matthys, A., 2009. Interpreting fold and fault geometries from within the lateral to oblique parts of slumps: a case study from the Anglo-Brabant Deformation Belt (Belgium). Journal of Structural Geology, 31: 1525-1539.

Frey, S.E., Dashtgard, S.E., 2012. Seaweed-assisted, benthic gravel transport by tidal currents. Sedimentary Geology, 265-266: 121-125.

Gibert, L., Sanz de Galdeano, C., Alfaro, P., Scott, P.G., Lopez Garrido, A.C., 2005. Seismic induced slump in Early Pleistocene deltaic deposits of the Baza Basin (SE Spain). Sedimentary Geology, 179: 279-294.

Gibert, L., Alfaro, P., García-Tortosa, F.J., Scott, G., 2011. Superposed deformed beds produced by single earthquakes 
(Tecopa Basin, California): Insights into paleoseismology. Sedimentary Geology, 235: 148-159.

Gladkov, A.S., Lobova, E.U., Deev, E.V., Korzhenkov, A.M., Mazeika, J.V., Abdieva, S.V., Rogozhin, E.A., Rodkin, M.V., Fortuna, A.B., Charimov, T.A., Yudakhin, A.S., 2016. Earthquake-induced soft-sediment deformation structures in Late Pleistocene lacustrine deposits of Issyk-Kul lake (Kyrgystan). Sedimentary Geology, 344: 112-122.

Hansen, E., 1971. Strain Facies. Springer, Berlin.

Haughton, P.D.W., Barker, S.P., McCaffrey, W.D., 2003. "Linked" debrites in sand-rich turbidite systems; origin and significance. Sedimentology, 50: 459-482.

Hempton, M.R., Dewey, J.F., 1983. Earthquake-induced deformational structures in young lacustrine sediments, East Anatolian Fault, southeast Turkey. Tectonophysics, 98: T7-T14.

Jiang, J., Zhong, N., Li, Y., Xu, H., Yang, H., Peng, X., 2016. Soft sediment deformation structures in the Lixian lacustrine sediments, eastern Tibetan Plateau and implications for postglacial seismic activity. Sedimentary Geology, 344: 123-134.

Kawakami, G., Kawamura, M., 2002. Sediment flow and deformation (SFD) layers: evidence for intrastratal flow in laminated muddy sediments of the Triassic Osawa Formation, Northeast Japan. Journal of Sedimentary Petrology, 72: 171-181.

Kim, S.B., Chough, S.K., Chun, S.S., 1995. Bouldery deposits in the lowermost part of the Cretaceous Kyokpori Formation, SW Korea: cohesionless debris flows and debris falls on a steep-gradient delta slope. Sedimentary Geology, 98: 97-119.

Kim, S.B., Chough, S.K., Chun, S.S., 2003. Tectonic controls on spatio-temporal development of depositional systems and generation of fining-upward basin fills in a strike-slip setting: Kyokpori Formation (Cretaceous), south-west Korea. Sedimentology, 50: 639-665.

Ko, K., Park, S., Kwon, C.W., 2015. Soft-sediment deformation structures in the Cretaceous Gyeokpori Formation of the Buan area, Korea: Structural characteristics, reconstruction of paleoslope and triggering mechanism of slump (in Korean with English abstract). Journal of Geological Society of Korea, 51: 545-560.

Ko, K., Kim, S.W., Lee, H.-J., Hwang, I.G., Kim, B.C., Kee, W.-S., Kim, Y.-S., Gihm, Y.S., 2017. Soft sediment deformation structures in a lacustrine sedimentary succession induced by volcano-tectonic activities: an example from the Cretaceous Beolgeumri Formation, Wido Volcanics, Korea. Sedimentary Geology, 358: 197-209.

Koh, H.J., Kwon, C.W., Park, S.I., Park, J., Kee, W.S., 2013. Geological Report of the Julpo and Wido-Hawangdeungdo sheets $(1: 50,000)$ (in Korean, with English abstract). Korea Institute of Geoscience and Mineral Resources.

Kwon, C.W., Ko, K., Gihm, Y.S., Koh, H.J., Kim, Y., 2017. Late Cretaceous volcanic arc system in southwest Korea: Distribution, lithology, age, and tectonic implications. Cretaceous Research, 75: 125-140.

Mazumder, R., Van Loon, A.J., Malviya, P., Arima, M., Ogawa, Y., 2016. Soft-sediment deformation structures in the Mio-Pliocene Misaki Formation within alternating deep-sea clays and volcanic ashes (Miura Peninsula, Japan). Sedimentary Geology, 344: 323-335.

Moretti, M., Sabato, L., 2007. Recognition of trigger mechanisms for soft-sediment deformation in the Pleistocene lacustrine deposits of the Sant'Arcangelo Basin (southern Italy): seismic shock vs. overloading. Sedimentary Geology, 196: 31-45.

Pisarska-Jamro y, M., Van Loon, A.J., Mleczak, M., Roman, M., 2019. Enigmatic gravity-flow deposits at Ujście (western Poland), triggered by earthquakes (as evidenced by seismites) caused by Saalian glacioisostatic crustal rebound. Geomorphology, 326: 239-251.

Rana, R., Sati, S.P., Sundrival, Y., Juval, N., 2016. Genesis and implication of soft-sediment deformation structures in high-energy fluvial deposits of the Alaknanda Valley, Garhwal Himalaya, India. Sedimentary Geology, 344: 263-276.

Rodríguez-Pascua, M.A., Calvo, J.P., de Vicente, G., Gomez Gras, D., 2000. Seismites in lacustrine sediments of the Prebetic Zone, SE Spain, and their use as indicators of earthquake magnitudes during the Late Miocene. Sedimentary Geology, 135: 117-135.

Salamon, T., 2015. Sedimentary record of a Scandinavian Ice Sheet drainage system and till deposition over subglacial obstacles promoting basal sliding (an example from southern Poland). Sedimentary Geology, 330: 108-121.

Sims, J.D., 1973. Earthquake-induced structures in sediments of Van Norman Lake, San Fernando, California. Science, 182: 161-163.

Sims, J.D., 1975. Determining earthquake recurrence intervals from deformational structures in young lacustrine sediments. Tectonophysics, 29: 141-152.

Tanner, L.H., Lucas, S.G., 2007. The Moenave Formation: Sedimentologic and stratigraphic context of the Triassic-Jurassic boundary in the Four Corners area, southwestern USA. Palaeogeography, Palaeoclimatology, Palaeoecology, 244: $111-125$.

Taşgín, C.K., Türkmen, I., 2009. Analysis of soft-sediment deformation structures in Neogene fluvio-lacustrine deposits of Çaybğaı Formation. Eastern Turkey. Sedimentary Geology, 218: 16-30.

Taşgín, C.K., Orhan, H., Türkmen, I., Aksoy, E., 2011. Soft-sediment deformation structures in the late Miocene Şelmo Formation around Adıyaman area, Southeastern Turkey. Sedimentary Geology, 235: 277-291.

Van Loon, A.J., Pisarska-Jamro y, M., Nartišs, M., Krievâns, M., Soms, J., 2016. Seismites resulting from high-frequency, high-magnitude earthquakes in Latvia caused by Late Glacial glacio-isostatic uplift. Journal of Palaeogeography, 5: 363-380.

Whitmore, J.H., Strom, R., 2010. Sand injectites at the base of the Coconino Sandstone, Grand Canyon, Arizona (USA). Sedimentary Geology, 230: 46-59.

Williams, E., 1960. Intra-stratal flow and convolute folding. Geological Magazine, 97: 208-214.

Woodcock, N.H., 1979. The use of slump structures as palaeoslope orientation estimators. Sedimentology, 26: 83-99. 